\title{
Pengaruh Ragi dan Waktu Fermentasi terhadap Produksi Alkohol Secara Fermentasi Berbahan Baku Gaplek Ubi Kayu (Manihot utillisima)
}

\author{
The Ragi and Fermentation Time Effect on Alcohol production by cassava (Manihot \\ utillisima) "Gaplek" fermentation

\section{P. Kianto Atmodjo}

Fakultas Teknobiologi, Universitas Atma Jaya Yogyakarta, Jl. Babarsari 44 Yogyakarta 55281

E-mail: kianto@mail.uajy.ac.id

\begin{abstract}
The research of the ragi and the fermentation time effect on alcohol production by cassava gaplek has been done. The aim of this research were to find out the best time fermentation and trade mark commercial ragi to produce alcohol. Time fermentation were 1 and 2 weeks. The ragi trade marks were NKL and MK. The result showed that the alcohol production was $15-17 \%$ in a week, and $18-20 \%$ in two week fermentation. The alcohol quantity which produced by both NKL and MK ragi were not significantly different.
\end{abstract}

Key words: fermentation, gaplek, alcohol

Diterima: 20 November 2007, disetujui: 26 Januari 2008

\section{Pendahuluan}

Alkohol atau etil alkohol $\left(\mathrm{CH}_{3} \mathrm{CH}_{2} \mathrm{OH}\right)$, mempunyai densitas $0,78506 \mathrm{~g} / \mathrm{ml}$ pada $25^{\circ} \mathrm{C}$, titik didih $78,4^{0} \mathrm{C}$, tidak berwarna dan mempunyai bau serta rasa yang spesifik (Kartika, 1990). Alkohol adalah hasil fermentasi lebih lanjut dari tape, dan diproduksi membutuhkan waktu 7-9 hari dengan hasil sekitar 5-20\%, tergantung dari jenis ketan (Atmodjo, 2006). Namun produksi alkohol ini dianggap masih cukup mahal, dikarenakan harga beras ketan per kg mencapai Rp. 5000,- sehingga harga alkohol yang diperoleh tentunya akan lebih tinggi sekitar 3-4 kali harga beras ketan. Padahal alkohol dipasaran seharga Rp. 7000-10000 per liter tergantung kualitasnya. Untuk itu perlu dicari bahan baku lain yang jumlahnya melimpah dan harganya murah.

Salah satu bahan baku yang kaya akan karbohidrat adalah ubi kayu (Manihot utilissima Pohl.) yang banyak dibudidayakan oleh masyarakat diantaranya adalah masyarakat daerah Kabupaten Gunung Kidul yang mampu menghasilkan ubu kayu per tahun minimal 700.000 ton tahun 2006 ini dan sebagian sekitar 250.000 ton dalam ujud gaplek yang dihargai Rp. 550-750 per kg (Werdiono, 2006). Gaplek adalah hasil olah pasca panen ubikayu dengan cara dikupas dan dikeringkan dibawah sinar matahari, yang merupakan khas dari daerah Gunung Kidul (Rukmana dan Yuyun, 2001). Kandungan karbohidrat dan energi ubi kayu tidak kalah dibanding beras merah dan beras giling, apalagi bila dibuat gaplek. kandungan karbohidrat tepung gaplek lebih tinggi daripada singkong yaitu sebesar 81\% (Tarwiyah, 2001), sehingga amat berpotensi untuk bahan baku pembuatan alkohol.

Alkohol dibuat melalui proses peragian ubi kayu yang menghasilkan produk tape ketela. Proses pembuatan tape ini melibatkan peran mikrobia campuran dalam bentuk ragi. Ragi adalah suatu inokulum padat yang mengandung berbagai jenis kapang, khamir, dan bakteri yang berfungsi sebagai starter dalam fermentasi tape (Hidayat, 2006). Inokulum ragi tape yang baik menurut Sarjono dan Wibowo (1988) adalah yang memenuhi 
kriteria-kriteria sebagai berikut : bersifat selektif terhadap mikrobia yang diinginkan, mikrobia tersebut mampu tumbuh dan berkembangbiak di dalam substrat yang diinginkan, stabil selama penyimpanan, dan mampu melakukan proses fermentasi dalam lingkungan yang sederhana dan mudah dikendalikan. Pada saat ini banyak ragi tape yang beredar dengan berbagai merek dagang, diantaranya adalah ragi NKL dan MK (Sulistyawan, 2002).

Selain ragi, faktor-faktor yang mempengaruhi fermentasi etanol antara lain adalah sumber karbon, $\mathrm{pH}$, suhu, sumber nitrogen, faktor tumbuh, oksigen, alkohol dan CO2. Selain itu, kondisi fisiologi inokulum, dan kualitas substrat pertumbuhan juga berpengaruh terhadap hasil yang diperoleh serta efisiensi fermentasi. Kondisi fisiologi inokulum tergantung pada faktor-faktor lingkungan, adanya mikrobia kontaminan akan sangat berpengaruh terhadap produk metabolit yang dihasilkan dan menghambat proses fermentasi (Najafpour et al., 2004).

Permasalahan yang berhasil diungkap dari penelitian adalah pertama lama proses pembentukkan alkohol dengan bahan dasar gaplek ubi kayu. Kedua adanya perbedaan antara ragi merk NKL dan MK dalam menghasilkan alkohol.

\section{Metode Penelitian}

Penelitian dilaksanakan pada bulan Januari sampai dengan Juni 2007 di Laboratorium Biopangan dan Industri atau lab. Instruksional II Fakultas Tekno Biologi Universitas Atma Jaya Yogyakarta.

Alat-alat yang digunakan yaitu: tabung reaksi, erlenmeyer $250 \mathrm{ml}$, labu ukur, waterbath, laminair flow Cabinet-Esco, mikropipet Socorex, spektrofotometer Genesys 10 UV, cawan petri, lampu Bunsen, buret, kompor, panci, dandang, kantong plastik, pipet ukur, pro pipet, gelas benda, mikroskop, alat distilasi uap, alkoholmeter, dan gelas ukur 100 ml.

Bahan-bahan yang digunakan dalam penelitian meliputi :gaplek ubi kayu dari kabupaten Gunung Kidul, ragi komersial lokal
(NKL dan MK) aquades steril, phenolpthalin, $\mathrm{NaOH} 0,1 \mathrm{~N}$, reagen Arsenomolibdat, reagen Nelson, larutan glukosa standar, asam sitrat 10\%, NA (Nutrien Agar), larutan laktofenol, dan methylen blue.

\section{Rancangan Percobaan}

Rancangan percobaan yang digunakan dalam penelitian ini adalah Rancangan Acak Lengkap dengan ulangan sebanyak tiga kali dibagi dua tahap. Tahap pertama meneliti waktu fermentasi yaitu satu minggu dan dua minggu. Tahap kedua menenliti dua macam ragi: NKL dan MK.

\section{Pembuatan tape gaplek ubi kayu (Id.wikipedia.org/wiki/Tape, 2006)}

Lima kilogram gaplek ubi kayu dipotong-potong berukuran $5 \mathrm{~cm}$ dicuci dan direndam dalam panci selama 10 menit, kemudian dikukus selama kurang lebih 30 menit sehingga agak lunak. Diangkat dan didinginkan, selanjutnya ditaburi ragi dengan perbandingan $5 \mathrm{~kg}$ gaplek : 5 butir ragi (1 butir = 5 gram), lalu disimpan dalam kantong plastik dengan berat $500 \mathrm{~g}$ dan dibiarkan pada suhu kamar.

\section{Penentuan kadar gula}

Tape gaplek ubi kayu diukur kadar gulanya dengan metode Nelson-Somogy (Sudarmadji et al., 1997) satu minggu dan dua minggu. Penentuan kadar gula diawali dengan pembuatan kurva standar dengan cara: larutan glukosa standar (10 mg glukosa anhidrat/100 $\mathrm{ml}$ ) diencerkan sehingga diperoleh larutan glukosa dengan konsentrasi 2, 4, 6, 8, dan 10 $\mathrm{mg} / 100 \mathrm{ml}$. Lima tabung reaksi yang bersih, diisi $1 \mathrm{ml}$ larutan glukosa standar, satu tabung diisi $1 \mathrm{ml}$ aquades sebagai blanko. Kemudian ke dalam masing-masing tabung ditambahkan 1 ml reagen Nelson dan semua tabung dipanaskan pada penangas air mendidih selama 20 menit. Tabung diambil dan didinginkan dalam gelas piala yang berisi air dingin hingga suhu tabung mencapai $25{ }^{\circ} \mathrm{C}$. Setelah dingin ditambahkan $1 \mathrm{ml}$ reagen Arsenomolibdat, digojok sampai semua endapan $\mathrm{Cu}_{2} \mathrm{O}$ yang ada larut kembali. Aquades sebanyak $7 \mathrm{ml}$ ditambahkan ke dalam larutan yang sudah tidak terdapat endapan $\mathrm{Cu}_{2} \mathrm{O}$, digojog sampai 


\section{P. Kianto Atmodjo}

homogen. Larutan yang sudah homogen diambil sebanyak $1 \mathrm{ml}$ dan ditambahkan $9 \mathrm{ml}$ aquades kemudian diukur Optical Density pada spektrofotometer dengan panjang gelombang $540 \mathrm{~nm}$, kemudian dibuat kurva standar hubungan antara kadar glukosa dan absorbansi.

Selanjutnya sampel sebanyak $1 \mathrm{ml}$ diambil dan dimasukkan dalam tabung reaksi yang bersih. Reagen Nelson sebanyak $1 \mathrm{ml}$ ditambahkan ke dalam larutan sampel dan selanjutnya diperlakukan sama seperti pada penyiapan kurva standar. Kadar gula pereduksi dalam satuan mg/100 ml dapat diperoleh dari kurva standar dan persamaan regresi linier yang didapatkan.

\section{Penentuan Kadar Alkohol}

\section{Distilasi alkohol (Kartika et al., 1997)}

Tape gaplek ubi kayu umur 1 dan 2 minggui diambil satu $\mathrm{kg}$ kemudian diperas untuk diambil cairannya, selanjutnya cairan ini didistilasi dengan menggunakan alat distilasi uap. Distilasi dilakukan dengan tabung Glinsky (distilasi dengan fraksionasi sederhana) atau distilasi biasa. Untuk memperoleh distilat yang baik dapat ditambahkan garam pada sampel yang didistilasi sehingga alkohol yang dihasilkan bebas dari air.

\section{Penentuan kadar alkohol menggunakan alkoholmeter (Anonim, 2005)}

Distilat dituangkan ke dalam gelas ukur $100 \mathrm{ml}$. Alkoholmeter dimasukkan secara perlahan ke dalam distilat. Alkoholmeter didiamkan sehingga dapat mengapung dengan stabil, dan didiamkan selama 2 menit sampai distilat menjadi tenang lalu dibaca angkanya. Persentase alkohol dalam satuan persen dibaca pada batang alkoholmeter yang berbatasan dengan distilat.

\section{Penentuan total jumlah khamir (Wibowo dan Ristanto, 1988)}

Penentuan total jumlah mikrobia untuk mengetahui jumlah mikrobia yang masih terdapat dalam peuyem ubi kayu dilakukan dengan mengambil $1 \mathrm{ml}$ sampel cairan tape ketan kemudian dimasukkan ke dalam $9 \mathrm{ml}$ aquades steril (pengenceran $1: 10$ ), kemudian digojog hingga homogen. Dari pengenceran tersebut diambil $1 \mathrm{ml}$ lagi untuk dimasukkan ke dalam tabung reaksi yang berisi $9 \mathrm{ml}$ aquades steril sehingga diperoleh pengenceran $1: 100$, selanjutnya dari sampel yang sudah diencerkan tersebut diambil $1 \mathrm{ml}$ dibiakkan di dalam medium dengan cara taburan. Pembiakkan khamir dilakukan pada medium MEA (Malt Extract Agar), Penanaman dilakukan menggunakan teknik sebar yaitu diambil sampel sebanyak $1 \mathrm{ml}$ ditambahkan ke medium agar sebanyak $15-20 \mathrm{ml}$ dalam cawan petri dengan suhu $45^{\circ} \mathrm{C}$ dan dibiarkan membeku. Cawan petri dibalik dan dieramkan pada suhu $20-25^{\circ} \mathrm{C}$ selama 5-7 hari. Koloni yang terjadi dihitung jumlahnya.

Pengamatan morfologi khamir dengan methylen blue. Gelas benda dan gelas penutup dibersihkan dengan alkohol sampai bebas lemak dan debu. Satu tetes larutan cat methylen blue diambil dan diletakkan di tengah-tengah gelas benda. Satu ose suspensi biakan khamir kemudian diletakkan diatas gelas benda yang telah diberi methylen blue dan ditutup dengan gelas penutup. Harus dijaga agar pada waktu meletakkan gelas penutup jangan sampai terbentuk gelembung udara dalam preparat, setelah itu diamati dengan mikroskop.

\section{Analisis data}

Data yang diperoleh dianalisis variansinya menggunakan ANOVA, dan bila beda nyata dilanjutkan dengan Duncan's Multiple Range Test (DMRT) dengan taraf kepercayaan 95\% (Gaspersz, 1994).

\section{Hasil dan Pembahasan}

\section{Pembuatan peuyem/tape}

Gaplek adalah ubi kayu yang telah dikupas kulitnya dan dikeringkan secara alami. Pada saat membuat tape dari gaplek timbul permasalahan yaitu gaplek ini tidak dapat jadi tape. Cara membuat tape ini didasarkan pengalaman peneliti dalam membuat tape dari beras ketan yang tidak membutuhkan waktu perendaman lama dan air yang banyak. Setelah mencoba berbagai cara, maka diperoleh cara membuat tape dari gaplek sebagai berikut: pertama gaplek dipotong kecil-kecil $(2-3 \mathrm{~cm})$ 
kemudian direbus selama 15 menit. Selanjutnya dimasak menggunakan dandang selama 2 jam. Gaplek dijaga jangan sampai terlalu matang supaya tetap utuh bentuknya. Langkah selanjutnya gaplek ini didinginkan di atas nyiru. Setelah didiamkan sekitar 2-3 jam, gaplek ditaburi ragi sampai merata dengan perbandingan satu butir ragi untuk $1 \mathrm{~kg}$ gaplek. Kemudian gaplek ini dimasukkan ke dalam kantong plastik dan ditutup tidak terlalu rapat agar masih ada sedikit udara. Gaplek difermentasi pada suhu kamar.

\section{Waktu fermentasi gaplek untuk produksi alkohol}

Gaplek difermentasi selama satu sampai dua minggu dengan asumsi bahwa jika hanya 3 hari saja rasa tape gaplek masih berasa manis, tanda baru terbentuk gula dari proses hidrólisis amilum oleh jamur. Gula yang terbentuk ini selanjutnya difermentasi menjadi alkohol dan produk yang lain oleh khamir. Waktu yang dibutuhkan untuk proses ini kurang lebih 3-4 hari. Tanda telah terbentuk alkohol adalah rasa manis berkurang, rasa dan bau alkohol bertambah. Proses pembentukan alkohol terus berlangsung sampai semua gula habis terkonversi. Apabila proses fermentasi ini berlanjut terlalu lama, maka akan timbul rasa asam sebagai akibat proses fermentasi lebih lanjut yang mengubah alkohol menjadi asam organik (Purwantari et al, 2004; Jefries, 2005).

Hasil penelitian pembuatan alkohol dari gaplek ubi kayu ini (Tabel 1) dengan variasi waktu fermentasi dapat diketahui bahwa volume cairan tape, kadar alkohol, serta bau dan rasa alkoholis hasil fermentasi dalam waktu 1 minggu lebih rendah dibandingkan 2 minggu, sedangkan kadar gula dan asam total lebih tinggi pada fermentasi satu minggu dibanding 2 minggu. Hasil ini membuktikan bahwa waktu fermentasi menentukan banyak sedikitnya alkohol yang terbentuk.

Banyaknya alkohol yang dihasilkan tidak kalah jauh dibandingkan dengan fermentasi tape dari bahan baku ketan, yaitu sekitar 2024\% (Atmodjo, 2006), apalagi ketan hitam yang sampai sebanyak $35 \%$, sedangkan gaplek ubi singkong hanya mampu mencapai $20 \%$. Namun demikian dengan harga gaplek ubi singkong (Rp 750 - Rp.1000 per kg) dan beras ketan (Rp. 7000- Rp.9000 per kg), maka hasil ini dirasa cukup baik dan kompetitif dalam produksi alkohol menggunakan bahan baku gaplek ubi singkong. Hasil ini tidak berbeda jauh dengan hasil-hasil penelitian fermentasi singkong yang diberitakan oleh berbagai media massa yaitu 6,5 kg singkong untuk menghasilkan alkohol dengan kadar 95\% (Yun, 2006).

\section{Produksi Alkohol menggunakan ragi yang beda merk}

Ragi merupakan campuran berbagai mikrobia yang akan melakukan proses fermentasi secara bertahap (Kasmidjo, 1991). Tahap pertama jamur benang menghidrolisis amilum menjadi gula sederhana (glukosa). Tahap berikutnya glukosa akan difermentasi menjadi alkohol oleh khamir. Selain jamur dan khamir, pada ragi seringkali dijumpai spora bakteri. Spora ini akan tumbuh menjadi sel bakteri di akhir proses hidrólisis amilum dan awal konversi gula menjadi alkohol. Akibat pertumbuhan bakteri akan menyebabkan timbul cita rasa selain rasa manis dan alkoholis yaitu masam.

Pembuatan ragi didasarkan pada proses penumbuhan jamur benang dan khamir pada tepung ubi atau beras, setelah tumbuh lebat dilakukan pengeringan dan dicampur dengan bumbu (bawang, lombok dsb) yang berperan sebagai pengawet. Setiap produk ragi memiliki keistimewaan masing-masing tergantung dari campuran bahan dan sumber mikrobianya.

Pada penelitian produksi alkohol dengan bahan baku gaplek ubi singkong menggunkan ragi yang terkenal di seputar DIY-Jawa Tengah yaitu NKL buatan dari Solo, dan ragi yang kurang terkenal (masih baru) adalah MK buatan dari Yogyakarta. Tabel 2. memperlihatkan bahwa alkohol yang diproduksi hampir sama yaitu $16 \%$ dari ragi MK dan 16,5\% dari ragi NKL.

Kemampuan ragi NKL dalam melakukan fermentasi yang lebih tinggi dibanding ragi MK didukung parameter lain terutamai total khamir dan kadar asam. Total khamir dari ragi NKL lebih tinggi dibanding ragi MK, yaitu 6,75 x $10^{8} \mathrm{sel} / \mathrm{ml}$ dibanding $4,2 \times 10^{8} \mathrm{sel} / \mathrm{ml}$ dan kadar asam dari fermentasi dengan ragi NKL $(0,8 \%)$ lebih rendah dibanding ragi $\mathrm{Mk}$ 


\section{P. Kianto Atmodjo}

(1,02\%). Hasil fermentasi alkohol dari bahan gaplek ini hasilnya lebih tinggi dibandingkan alkohol dari Pabrik alkohol dikota Solo yang menggunakan bahan baku molase, yaitu $16 \%$ dibanding 10\%. Selain itu, hasil di atas juga lebih dari hasil penelitian Purwantari et al.( 2004) dan Nowak ( 2001).

Tabel 1. Pengaruh waktu fermentasi tape gaplek ubi singkong terhadap produksi alkohol

\begin{tabular}{lcc}
\hline \hline \multicolumn{1}{c}{ Parameter } & \multicolumn{2}{c}{ Waktu Fermentasi } \\
\cline { 2 - 3 } & 1 Minggu & 2 Minggu \\
\hline \hline Volume cairan (ml/500g) & $150-170$ & $210-300$ \\
Total khamir sel x 10\%l & $4,55-5,05$ & $6,25-11,1$ \\
Kadar gula mg/100ml & $14,5-19,39$ & $8,76-8,82$ \\
Kadar asam total \% & $1,17-1,27$ & $0,78-1,14$ \\
Kadar Alkohol \% & $15-17,5$ & $18-20$ \\
Bau Asam & Kuat & lemah \\
Bau Alkohol & Kuat & kuat \\
Warna ubi & Putih & Agak kuning \\
Penampakan uni & Utuh agak keras & lembek \\
\hline \hline
\end{tabular}

Tabel 2. Produksi alkohol berbahan dasar singkong dengan menggunakan ragi NKL dan MK

\begin{tabular}{lcc}
\hline \multicolumn{1}{c}{ Parameter } & \multicolumn{2}{c}{ Merk Ragi } \\
\cline { 2 - 3 } & MK & NKL \\
\hline \hline Volume cairan $\mathrm{ml} / \mathrm{kg}$ & 505 & 550 \\
Total khamir sel x $10^{8} / \mathrm{ml}$ & 4,2 & 6,75 \\
Kadar Alkohol \% & 16 & 16,5 \\
Kadar gula mg/100 ml & 8,78 & 8,75 \\
Kadar asam total \% & 1,02 & 0,8 \\
Bau Asam & lemah & Kuat \\
Bau Alkohol & kuat & Kuat \\
Warna ubi & putih & Putih \\
\hline \hline
\end{tabular}

\section{Kesimpulan}

Berdasarkan hasil penelitian di atas, maka dapat disimpulkan bahwa produksi alkohol berbahan baku gaplek ubi singkong sebaiknya menggunakan ragi merk NKL lebik baik dibanding MK. Adapun waktu fermentasi yang dibutuhkan dalam fermentasi alkohol ini satu minggu. Adapun alkohol yang dihasilkan memiliki kadar 16-16,5\%.

\section{Daftar Pustaka}

Anonim. 2005. Alcoholmeter Use Instruction. www. brewhaus.com/Alcoholmeter-Instructions.htm. 04/17/2005.

Atmodjo, K. 2006, Pengaruh Variasi Beras Ketan (oryza sativa var. Glutinosa L.) dan Suhui fermentasi Terhadap produksi Alkohol. Biota XI (3): 152-158.
Gaspersz, V. 1994, Metode Perancangan Percobaan, Penerbit CV. Armico, Bandung.

Hidayat, N. 2006. Produksi Bioetanol. http://www.migasindonesia.com. 09/16//2006.

Id.wikipedia.org/wiki/Gaplek. 07/15/2006.

Jefrries, T.W. 2005. Ethanol Fermentation on The Move. Nature Biotechnol. 23 (1): 40- 41.

Kartika, B., Guritno, A.D. dan Ismoyowati. 1997. Petunjuk Evaluasi Produk industry hasil pertanian. PAU-Pangan dan Gizi. Universitas Gadjah Mada Yogyakarta.

Kasmidjo, R.B. 1991. Pembuatan dan Pemanfaatan Ragi, Pusat Antar Universitas Pangan dan Gizi, Universitas Gajah Mada, Yogyakarta.

Kuswanto, K.R. 1994. Food Fermentation of Cassava In Indonesia, Application and Control of Microorganism In Asia, Proceedings of The International Workshop On Application and Control of Microorganism In Asia, Science and Technology Agency, RIKEN, Japan International Science and Technology Exchange Centre. 
Purwantari E.P., Susilowati, A. dan Setyaningsih, R. 2004. Fermentasi Tepung Ganyong (Cannna edulis Kerr.) untuk Produksi Etanol oleh Aspergillus niger dan Zymomonas mobilis. J. Bioteknol. 1 (2): 43-47.

Najafpour, G., Younesi, H., Syahidah dan Ismail, K. 2004. Ethanol Fermentation in an Immobilized Cell Reactor using Saccharomyces cerevisiae. Biores Technol. 92 (3): 251-60.

Nowak, J. 2001. Comparison of Polish Industrial Distellery Yeast with Ethanol Producing Bacteria Zymomonas mobilis, Elec. Pol. Agricul Univ., FoodScience and Technol, http://www.ejpau.media.pl/series/volume4/iss ue2/food/art-06.html. 09/08/2006.

Rukmana, R. dan Yuyun, Y. 2001. Ubi kayu, Budidaya dan Pasca Panen.

Sardjono dan Wibowo, D. 1988. Mikrobiologi Pengolahan Pangan, Pusat Antar Universitas Pangan dan Gizi, Universitas Gajah Mada, Yogyakarta.

Sudarmadji, S., Haryono, B. dan Suhardi. 1997. Prosedur Analisa untuk Bahan Makanan dan Pertanian. Universitas Gadjah Mada Yogyakarta.

Sulistyawan, R.D.T. 2002. Mutu Tape 4 Macam Beras Ketan Lokal. Skripsi. Fakultas Teknobiologi Universitas Atma Jaya Yogyakarta.

Werdiono, D. 2006. Gaplek Tidak Hanya Penuhi Pasar Lokal. Harian KOMPAS. WWW. Kompas. Com. 03/06/2006.

Wibowo, D. dan Ristanto. 1988. Petunjuk Khusus Deteksi mikrobia Pangan, PAU-Pangan dan Gizi, Universitas Gadjah Mada Yogyakarta.

Yun. 2006. Energi Alternatif dari Singkong sampai dengan Aren. Kompas.Net. 